Volume 2, Nomor 2, Maret 2022, hlm 81-87

BEMAS: JURNAL BERMASYARAKAT

p ISSN 27455866 | e ISSN 27457958

\title{
Education about The Utilization of Cassava Starch (Tapioca) for Health and Making Snack
}

\author{
Suprapto $^{1 *}$, Endang Nur Widiyaningsih ${ }^{2}$, Rima Munawaroh ${ }^{3}$ \\ ${ }^{1 *}, 3$ Department of Pharmacy, Universitas Muhammadiyah Surakarta, Indonesia \\ ${ }^{2}$ Department of Nutrition, Universitas Muhammadiyah Surakarta, Indonesia \\ 1*,2,3 J1. A. Yani, Mendungan, Pabelan, Kec. Kartasura, Kabupaten Sukoharjo, Jawa Tengah 57169
}

\section{INFORMASI ARTIKEL}

\section{Article History:}

Submission:10/11/2021

Revised:28/11/2021

Accepted: 10/12/2021

* Korespondensi:

Suprapto

sup215@ums.ac.id

\begin{abstract}
Cassava (Manihot utilissima (Pohl.)) is one of the most widely distributed plants in Indonesia, easy to cultivate, obtain and relatively cheap price. Cassava starch is a type of material that is multifunctional as an excipient in the pharmaceutical field, has many benefits for health and is a potential food source for the community. Tapioca starch or cassava starch can be used as filler, binder and disintegrant in tablet and capsule formulations. Colomadu people in general know cassava only as a source of snacks, but do not know the benefits of cassava in the fields of pharmacy, health and nutritional value. The purpose of the service activity is to provide understanding and understanding for the community, especially Kleben, Gedongan, Colomadu Karanganyar on the use of cassava in the pharmaceutical, health and food fields. This dedication method is by way of presentations through power points, discussions and questions and answers. This service involves local community leaders to coordinate and invite the community as objects of service activities and the general public, both teenagers, adults and parents. The results of this service were felt to be very useful for the local community, which was shown by the enthusiasm of the people who came, asked and wanted a follow-up activity in the form of the practice of making various menu recipes that have been explained. This service activity is expected to increase public knowledge about the optimal use of cassava starch in the pharmaceutical, health and food fields. This activity is also expected to be able to open horizons and as a motivation for the community to open up business opportunities for making food from cassava starch (tapioca).
\end{abstract}

Keywords: Cassava amylum, snack food

\section{Edukasi Tentang Pemanfaatan Amilum Singkong (Tapioka) untuk Kesehatan dan Pembuatan Makanan Jajanan}

ABSTRAK

Singkong (Manihot utilissima (Pohl.) merupakan salah satu tanaman yang tersebar luas di Indonesia, mudah dibudidayakan, diperoleh dan harganya relatif murah. Amilum singkong merupakan jenis bahan yang bersifat multifungsi sebagai eksipien dalam bidang farmasi, banyak manfaat untuk 
Edukasi Tentang Pemanfaatan Amilum Singkong (Tapioka) untuk Kesehatan dan Pembuatan Makanan Jajanan

\section{PENDAhUluan}

kesehatan dan sumber pangan yang potensial bagi masyarakat. Pati tapioka atau pati singkong dapat digunakan sebagai bahan pengisi (filler), pengikat (binder) dan penghancur (disintegrant) dalam formulasi sediaan tablet dan kapsul. Masyarakat Colomadu secara umum mengenal singkong baru sebatas sebagai sumber pangan, namun belum mengetahui manfaat singkong dalam bidang kesehatan dan nilai gizinya. Tujuan kegiatan pengabdian adalah untuk memberikan pengertian dan pemahaman bagi masyarakat khususnya Kleben, Gedongan, Colomadu Karanganyar tentang manfaat amilum singkong (tapioka) untuk Kesehatan dan pembuatan makanan jajanan. Metode pengabdian ini dengan cara presentasi melalui power point, diskusi dan tanya jawab. Pengabdian ini melibatkan tokoh masyarakat setempat untuk mengkoordinir dan mengundang masyarakat sebagai obyek kegiatan pengabdian dan masyarakat umum, baik remaja, dewasa dan orang tua. Hasil pengabdian ini dirasakan sangat bermanfaat bagi masyarakat setempat yang ditunjukkan antusias masyarakat yang datang, bertanya dan menginginkan adanya kegiatan follow up berupa praktek pembuatan berbagai resep menu yang telah dijelaskan. Kegiatan pengabdian ini diharapkan dapat meningkatkan pengetahuan masyarakat tentang pemanfaatan pati singkong secara optimal dalam bidang kesehatan dan pangan. Kegiatan ini juga diharapkan mampu membuka cakrawala dan sebagai motivasi masyarakat untuk membuka peluang usaha makanan berbahan dasar amilum singkong (tapioka).

Kata kunci: Amilum Singkong; makanan jajanan

Karanganyar merupakan salah satu kabupaten di Soloraya yang memiliki wilayah sangat luas dibanding 5 kabupaten lainnya. Karanganyar memiliki banyak sumber daya manusia, subur tanahnya dan kaya sumber daya alam, sangat besar potensi usaha dan peluang pasarnya. Colomadu adalah sebuah kecamatan di Kabupaten Karanganyar yang berada di barat Kota Surakarta. Letak Kecamatan ini secara geografis terpisah dari kecamatan-kecamatan lainnya (eksklave). Sebelah barat dan utara berbatasan dengan Kabupaten Boyolali, sebelah timur berbatasan dengan Kota Surakarta, dan sebelah selatan berbatasan dengan Kabupaten Sukoharjo. Jumlah Penduduk Se-Kecamatan Colomadu adalah 61.843 Jiwa. Jenis Tanah di Kecamatan Colomadu adalah Regosol Kelabu[1] Tata letak tempat pengabdian berjarak sekitar $5 \mathrm{~km}$ sebelah utara dari Fakultas Farmasi UMS Surakarta.

Desa Gedongan terdiri dari beberapa dusun Gedongan, Kleben, Pepe, Tanon Kidul, dan Tanon Lor. Ada beberapa perumahan atau kluster berdiri di wilayah desa Gedongan, ada 2 pasar yakni pasar Colomadu dan pasar Klodran yang merupakan potensi Colomadu sebagai peluang pemasaran[2]. Terdapat 3 unit puskesmas yang dapat memudahkan akses penduduk untuk periksa dan konsultasi kesehatan. Inilah potensi yang sangat besar yang dimiliki desa Gedongan Colomadu, namun belum bisa diberdayagunakan secara optimal dan masih perlu pengembangan dan ditingkatkan ke depannya.

Mata pencaharian penduduk asli Desa Gedongan bervariasi mulai dari petani, buruh tani, pedagang, pegawai swasta dan pegawai pemerintah. Sebagian besar tingkat sosial ekonomi penduduk asli juga bervariasi dari yang sosial ekonominya rendah sampai yang sosial ekonominya tinggi. Sebagian besar para wanita penduduk asli Desa Gedongan adalah sebagai ibu rumah tangga. Hasil pengamatan penulis menunjukkan banyak ibu-ibu yang kurang produktif. Mereka hanya sebagai ibu rumah tangga yang melakukan aktivitas di rumah dan mempunyai banyak waktu luang.

Banyak jenis dan macam sumber tepung di pasaran seperti gandum, tapioka, garut, ganyong, jagung, beras, kentang, ubi/taro, sagu, dan lain-lain. Salah satu tepung yang sudah dikenal oleh 
masyarakat adalah tapioka yaitu tepung dari singkong[3]. Tapioka ini adalah tepung yang mudah didapatkan dan harga relatif murah sehingga sangat terjangkau oleh masyarakat[4]. Tapioka ini telah banyak digunakan masyarakat sebagai bahan untuk membuat berbagai macam makanan[5]. Namun masyarakat ternyata masih banyak yang belum tahu manfaat tapioka dalam bidang Kesehatan dan pangan [6]. Inilah celah yang belum banyak disentuh oleh pemerintah maupun pihak swasta terhadap manfaat singkong, tepung dan pati singkong dalam bidang kesehatan dan olahan makanan jajanan.

Oleh karena itu, program pengabdian pada masyarakat ini sangat penting dilaksanakan sebagai upaya untuk meningkatkan pemahaman dan pengetahuan terhadap manfaat tepung dan amilum singkong dalam bidang Kesehatan dan Pangan. Program pengabdian ini penting bagi masyarakat untuk meningkatkan pengetahuan dan keterampilan[7], peluang usaha dan bisnis mengenal variasi olahan tepung dan pati singkong[8]. Hal ini dapat digunakan sebagai upaya untuk menambah pendapatan keluarga terlebih di masa pandemi covid-19 yang belum berakhir sampai hari ini.

\section{METODE PELAKSANAAN}

Metode pelaksanaan pengabdian pada masyarakat ini penulis dibagi menjadi tiga (3) yakni:

a) Edukasi dengan cara menggunakan media power point.

Edukasi ini dilakukan dengan cara ceramah dengan menggunakan media power point. Pada metode ini penulis menjelaskan terkait manfaat amilum singkong dalam bidang kesehatan dan pangan.

b) Diskusi dan tanya jawab.

Pada sesi ini penulis memberikan kesempatan kepada audien untuk bertanya tentang hal-hal yang belum jelas dari materi yang telah disampaikan. Penulis memberikan jawaban dan klarifikasi atas pertanyaan yang diajukan. Penulis juga menanyakan sesuatu pada audien sehingga terjadi dialog interaktif dan suasana menjadi lebih hidup dan segar.

c) Pembuatan makanan jajanan berbahan utama amilum singkong. Pada metode ini penulis membuat video yang berisi tentang salah satu contoh cara membuat makanan jajanan berbahan utama amilum singkong dan dibagikan kepada audien agar bisa digunakan sebagai acuan dan diharapkan bisa dipraktekkan di rumah.

\section{HASIL DAN PEMBAHASAN}

Sesuai dengan urutan dalam metode pelaksanaan maka hasil dan pembahasan pengabdian pada masyarakat ini penulis juga bagi menjadi tiga (3) sesi yakni: presentasi dengan power point, diskusi dan tanya jawab, dan video tutorial pembuatan makanan berbahan amilum singkong.

\subsection{Presentasi dengan power point}

Pada metode ini penulis menjelaskan terkait manfaat amilum singkong dalam bidang farmasi, kesehatan dan pangan[9]. Beberapa istilah yang perlu diluruskan bahwa tepung berbeda dengan amilum. Tepung adalah serbuk atau powder atau flour atau pulveres, sedangkan pati adalah amilum (amylum/starch). Tepung kanji atau tepung Aci atau tepung TAPIOKA adalah tepung yang terbuat (yang diekstrak) dari umbi singkong[10], dikenal juga tepung singkong. Sebagian besar masyarakat belum paham perbedaan antara tepung dan pati singkong. Daur perubahan singkong menuju pati dapat dilihat pada gambar 1[11]. 
Edukasi Tentang Pemanfaatan Amilum Singkong (Tapioka) untuk Kesehatan dan Pembuatan Makanan Jajanan

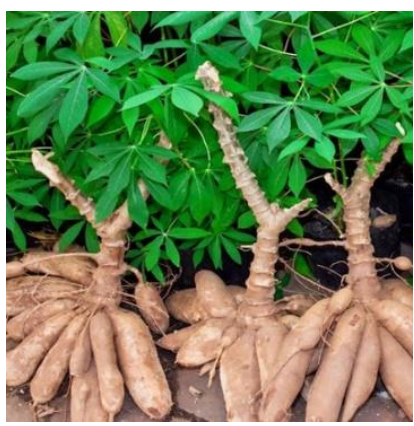

a. Singkong

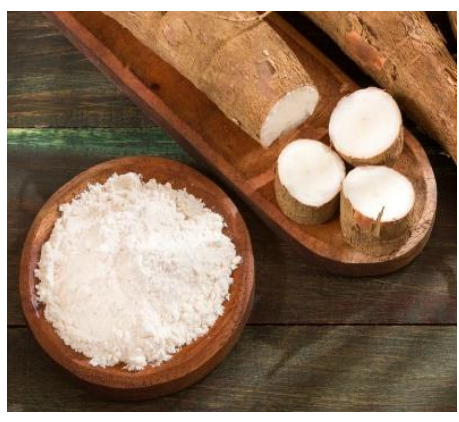

b. Tepung Singkong

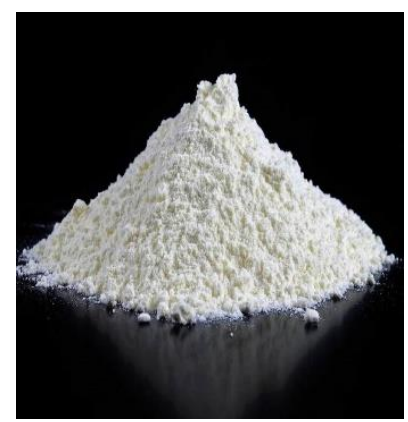

c. Pati singkong

Gambar 1. Daur perubahan singkong menuju pati [11] (https://www.prjctreoco.com/2021/03/05/cara-buat-tepung-singkong/)

Berdasarkan data dari Tabel Komposisi Pangan Indonesia (TKPI) tahun 2017, tiap $100 \mathrm{~g}$ tepung tapioka mengandung zat gizi berupa energi 363 kalori; protein $1,1 \mathrm{~g}$; karbohidrat $(\mathrm{KH}) 88,2 \mathrm{~g}$; lemak 0,5 g; serat 0,9 g; vitamin B1 (Thiamin: 0,04 mg) dan B3 (Niasin: 0,4 mg); dan Mineral (kalsium 84 $\mathrm{mg}$, fosfor $125 \mathrm{mg}$, besi $1 \mathrm{mg}$, natrium $1 \mathrm{mg}$, seng 0,1 mg, dan kalium 7,1 mg)[12]. Dalam bidang farmasi Amilum bermanfaat sebagai bahan pengikat (binder), pengisi (filler/diluent), penghancur (disintegrant), dan pelicin (pelincir). Beberapa manfaat dalam bidang Kesehatan adalah untuk membantu menaikkan berat badan (BB), menjaga kesehatan pencernaan (usus), menjaga kesehatan tulang, mengatasi nyeri asam lambung (dispepsia), menjaga tekanan darah normal, dan mendukung sistem metabolisme.

1) Membantu peningkatan berat badan (BB)

Mengkonsumsi makanan dari olahan tepung tapioka bisa menjadi solusi bagi yang ingin menaikkan berat badan (BB). Terdapat penelitian yang mengatakan bahwa kandungan karbohidrat pada tepung kanji ternyata bisa membantu dalam menaikkan berat badan. Jadi tepung tapioka memang sangat cocok untuk orang yang ingin menaikkan berat badan atau orang berbadan kurus.

2) Menjaga kesehatan pencernaan (usus)

Adanya kandungan serat di dalam tepung tapioka tersebut bermanfaat untuk menjaga kesehatan pencernaan. Tepung tapioka mampu mencegah sembelit, nyeri usus, dan perut kembung.

3) Menjaga kesehatan tulang.

Di dalam tepung tapioka terdapat banyak kandungan kalsium dan fosfor yang berguna dan dibutuhkan dalam menjaga kesehatan tulang. Dampak jangka panjang mengkonsumsi makanan dari olahan tepung tapioka, adalah mampu mencegah penyakit tulang seperti osteoporosis.

4) Mengatasi nyeri asam lambung (dispepsia).

Seseorang yang menderita maag akan merasakan nyeri yang berasal dari lambung. Penyebab terjadinya maag antara lain pola makan yang tidak teratur, stres atau banyak pikiran, penggunaan obat-obat tertentu yang terlalu keras, konsumsi alkohol dan rokok yang berlebihan. Singkong memiliki sifat untuk bisa merekatkan bahan-bahan lain seperti halnya fungsi lem (mucilago). Oleh karena itu, mengkonsumsi tepung kanji dapat membantu menebalkan lapisan lambung secara alami, sehingga asam lambung dapat teratasi.

5) Menjaga tekanan darah normal.

Kandungan kalium $(\mathrm{K})$ yang ada di dalam tepung kanji mampu menjaga tekanan darah tetap dalam kondisi norma. Tekanan darah normal sangat baik untuk kesehatan jantung.

6) Mendukung sistem metabolisme.

Kandungan vitamin B1 (thiamin) dan Niasin (B3) dapat digunakan untuk memperlancar metabolisme tubuh dalam membentuk energi, mengendalikan kolesterol dan Kesehatan kulit. 
Vitamin B1 (tiamin) adalah zat gizi yang berperan penting dalam pembentukan energi. Tubuh membutuhkan vitamin ini untuk menjaga fungsi sistem saraf, jantung dan otot agar bekerja dengan baik. Niasin adalah vitamin B3 yang termasuk ke dalam keluarga vitamin B kompleks.

\subsection{Diskusi dan tanya jawab}

Pada sesi ini penulis memberikan kesempatan kepada audien untuk bertanya tentang hal-hal yang belum jelas. Penulis memberikan jawaban dan klarifikasi atas pertanyaan yang diajukan. Penulis juga menanyakan sesuatu pada audien sehingga terjadi dialog interaktif dan suasana menjadi lebih hidup dan segar. Kegiatan ini dilaksanakan di dalam masjid setelah kegiatan sholat subuh berjamaah. Penulis memberikan penjelasan selama 30 menit kemudian dilanjutkan dengan kegiatan tanya jawab. Beberapa peserta mengajukan pertanyaan yang berhubungan dengan manfaat tapioka dalam kehidupan sehari-hari. Kegiatan penyuluhan dan diskusi dari peserta sebagaimana terlihat pada Gambar 2.

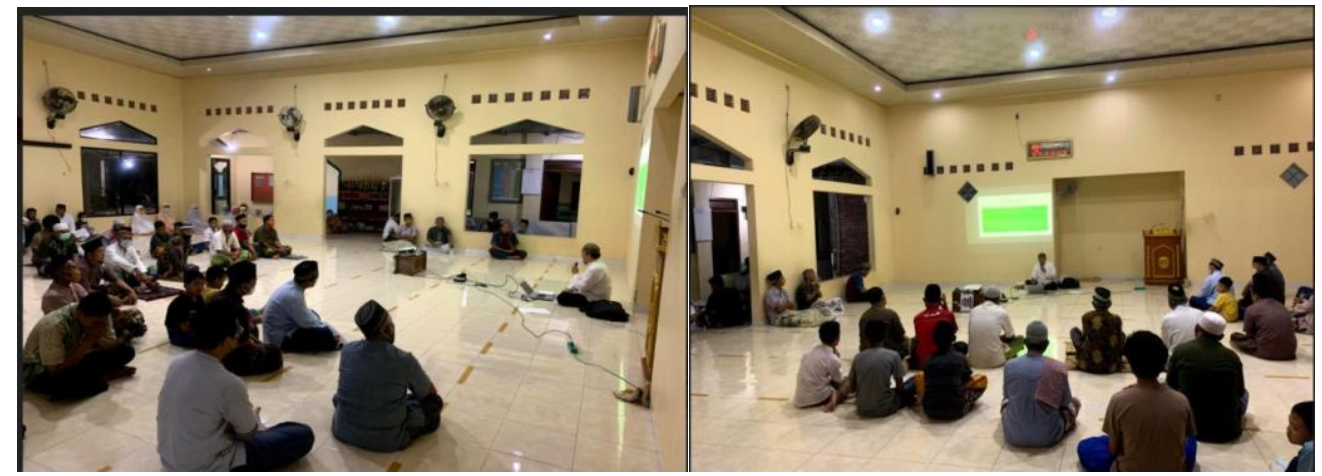

Gambar 2. Kegiatan presentasi, diskusi dan tanya jawab.

\subsection{Pembuatan makanan berbahan amilum singkong (tapioka)}

Penulis membuat video yang berisi tentang salah satu contoh cara membuat snack makanan berbahan amilum singkong (tapioka) dan dibagikan kepada audien agar bisa digunakan sebagai acuan dan diharapkan bisa dipraktekkan di rumah masing-masing. Rencana awal kegiatan pelatihan pembuatan makanan jajanan berbahan tapioka ini akan didemosntrasikan secara langsung namun kondisi PPKM tidak memungkinkan untuk dilaksanakan secara langsung. Oleh karena itu penulis membuat video tutorial ini sebagai pengganti kegiatan demonstrasi secara langsung.

Alamat online video tutorial pembuatan makanan jajanan dari tapioka adalah https://drive.google.com/file/d/1H IGRU4aj5EUdr7CPNW0UMZJuoiQ2bqG/view. Video tutorial ini dikirim melalui whatsapp.

Jenis makanan yang bisa diolah dari tapioka banyak sekali bisa berupa jajanan kering atau jajanan basah. Salah satu makanan jajanan yang bisa dikembangkan dari tapioka adalah gabus bayam dan gabus ubi ungu [13]. Makanan jajanan ini merupakan pengembangan menu makanan jajanan berbahan dasar tapioka yang dikombinasikan dengan sayur bayam atau ubi ungu sebagai sumber serat, vitamin dan antioksidan untuk meningkatkan nilai gizi[11] Bila hanya berbahan dasar tapioka saja maka hanya mengandung sumber zat gizi makro saja yaitu karbohidrat dan protein sehingga untuk memperkaya zat gizi mikro maka perlu penambahan bahan lain yaitu bayam dengan pertimbangan mudah didapat, harga terjangkau dan sayuran yang tidak asing bagi masyarakat pada umumnya. Bayam juga termasuk sayur yang mudah ditanam dan mudah tumbuh sehingga dari segi harga lebih ekonomis tetapi bernilai gizi tinggi. Contoh jajanan kering gabus bayam dan gabus ubi ungu terlihat pada Gambar 3. 
Edukasi Tentang Pemanfaatan Amilum Singkong (Tapioka) untuk Kesehatan dan Pembuatan
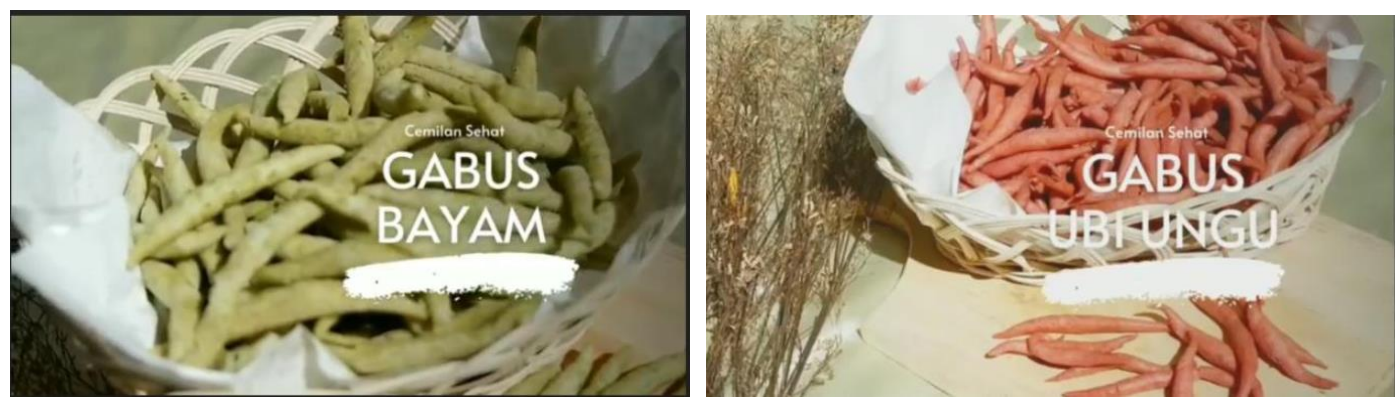

Gambar 3. Contoh jajanan kering gabus bayam dan gabus ubi ungu.

Demikian juga dengan ubi ungu yang mudah didapatkan masyarakat di pasar dengan harga yang relatif murah. Makanan jajanan ini dibuat dengan bahan utama tapioka, telur, margarin, garam, lada[14]. Pembuatan makanan jajanan ini relatif mudah sehingga sangat efektif untuk dipraktekkan di rumah dan biaya yang dikeluarkan juga tidak banyak. Pembuatan makanan jajanan dari tapioka yang ditambahkan bayam atau ubi ungu merupakan salah satu camilan yang menyehatkan di masa pandemi covid-19. Pada masa pandemi covid-19 sangat penting untuk meningkatkan sistem imun tubuh dengan makanan yang menyehatkan dan tinggi antioksidan[15]. Kelebihan lainnya, bila membuat makanan camilan sendiri di rumah akan lebih terjamin dari segi kualitas nilai gizi dan kebersihan karena di masa pandemic ini dituntut untuk tetap menjaga kesehatan diri.

\section{SIMPULAN}

Pati singkong (tapioca) merupakan bahan baku yang mudah diperoleh dan relatif murah harganya serta aman digunakan. Pati singkong bersifat multifungsi yang dapat dimanfaatkan dalam banyak bidang Kesehatan dan Pangan. Kegiatan pengabdian pada masyarakat ini telah berjalan sesuai dengan rencana. Tokoh masyarakat selaku koordinator mampu menggerakkan masyarakat untuk datang pada acara ini. Pengabdian pada masyarakat ini dirasakan sangat bermanfaat bagi masyarakat setempat yang ditunjukkan antusias masyarakat yang datang, bertanya dalam diskusi dan menginginkan adanya kegiatan follow up berupa praktek pembuatan berbagai resep menu yang telah dijelaskan. Kegiatan pengabdian ini diharapkan dapat meningkatkan pengetahuan masyarakat tentang pemanfaatan pati singkong secara optimal untuk kesehatan dan pembuatan makanan jajanan.

\section{UCAPAN TERIMA KASIH}

Pada kesempatan ini penulis mengucapkan terima kasih kepada UMS yang telah memberikan hibah penelitian terintegrasi (HIT) pada periode 2021 melalui Fakultas Farmasi UMS dengan nomor kontrak 47/FF/A.3-III/II/2021. Alhamdulillah dengan pendanaan program HIT tersebut penulis dapat melaksanakan kegiatan pengabdian pada masyarakat ini dengan lancar dan baik sesuai dengan rancangan jadwal.

\section{DAFTAR PUSTAKA}

[1] "https://www.karanganyarkab.go.id/20110104/kecamatan-colomadu/." https://www.karanganyarkab.go.id/20110104/kecamatan-colomadu/.

[2] D. Prihadi and Y. Mulyana, "Efektivitas E-Commerce dan Media Sosial untuk Meningkatkan Kinerja Pemasaran Perdagangan Pasar Tradisional," J. Ilm. FIFO, vol. 11, no. 1, 2019, doi: 10.22441/fifo.2019.v10i1.004.

[3] A. MUSTAFA, "Analisis Proses Pembuatan Pati Ubi Kayu (Tapioka) Berbasis Neraca Massa," Agrointek, vol. 9, no. 2, p. 118, 2016, doi: 10.21107/agrointek.v9i2.2143.

[4] F. Ramadhani and E. S. Murtini, "Pengaruh Jenis Tepung Dan Penambahan Perenyah Terhadap Karakteristik Fisikokimia Dan Organoleptik Kue Telur Gabus Keju," J Pangan dan Agroindustri, vol. 5, no. 1, 2017. 
[5] Z. H. Hassan, "Aneka tepung berbasis bahan baku lokal sebagai sumber pangan fungsional dalam upaya meningkatkan nilai tambah produk pangan lokal," Pangan, vol. 23, no. 1, pp. 93107, 2014.

[6] Lina listiana, "PEMBERDAYAAN KETERAMPILAN BERPIKIR DALAM PEMBELAJARAN BIOLOGI MELALUI MODEL KOOPERATIF TIPE GI (GROUP INVESTIGATION) DAN TTW (THINK, TALK, WRITE)," Jurnal, no. 2, 2011.

[7] Yanti Anggraini, R. Dewi Mutia, Rizky Wahyu Hadiyana, and Djoko Subali, "Pendampingan Kewirausahaan Berbasis Digital Dan Penggunaan Bahasa Inggris Untuk Pelaku Usaha Pemula,” BEMAS J. Bermasyarakat, vol. 2, no. 1, 2021, doi: 10.37373/bemas.v2i1.127.

[8] A. F. Hery Soegiharto and Sudarman, "Pendampingan Pembelajaran Keterampilan Secara Daring di Pondok Pesantren Tarbiyatul Iman Malang," BEMAS J. Bermasyarakat, vol. 2, no. 1, 2021, doi: 10.37373/bemas.v2i1.131.

[9] E. T. A. Multi Karina Sa"diah, Pengembangan Kuliner. 2017.

[10] S. Sofyani, J. E. A. Kandou, and M. F. Sumual, "PENGARUH PENAMBAHAN TEPUNG TAPIOKA DALAM PEMBUATAN BISKUIT BERBAHAN BAKU TEPUNG UBI BANGGAI (Dioscorea alata L.)," J. Teknol. Pertan. (Agricultural Technol. J., vol. 10, no. 2, 2020, doi: 10.35791/jteta.10.2.2019.29117.

[11] C. E. Ayuningtyas, "Preferensi konsumen terhadap organoleptik cookies non terigu," Penelit. Gizi dan Makanan, vol. 42, no. 2, pp. 81-86, 2019, [Online]. Available: https://www.neliti.com/publications/223576/hubungan-asupan-energi-lemak-dan-serat-denganrasio-kadar-kolesterol-total-hdl.

[12] Izwardy D, Mahmud MK, Hermana, and Nazarina, Tabel Komposisi Pangan Indoensia 2017. 2017.

[13] E. Pranita, "Potensi Pertanian Ubi Kayu di Indonesia Menjanjikan Halaman all Kompas.com," 26 September, 2019. .

[14] T. Widiantara, "KAJIAN PERBANDINGAN TEPUNG KACANG KORO PEDANG (Canavalia ensiformis) DENGAN TEPUNG TAPIOKA DAN KONSENTRASI KUNING TELUR TERHADAP KARAKTERISTIK COOKIES KORO,” Pas. Food Technol. J., vol. 5, no. 2, p. 146, 2018, doi: 10.23969/pftj.v5i2.1045.

[15] Kemenkes RI, "Panduan Gizi Seimbang Pada Masa Covid-19," Kementerian Kesehatan Republik Indonesia. p. 31, 2020. 